\title{
Effect of Aqueous Extract of Capparis spinosa on Serum Antioxidant Status in Paracetamol Treated Rats
}

\author{
Hussain I. AL-Khan \\ Department of Biology \\ College of Science \\ Mosul University
}

(Received 3/1/2010 ; Accepted 26 / 4 / 2010)

\begin{abstract}
Protective effect of aqueous extract of Capparis spinosa was studied on paracetamol induced liver damage in rats by administrating the rats with $1 \mathrm{gm} / \mathrm{kg}$ of body weight of paracetamol for 21days. Pretreatment rats with 100 and $200 \mathrm{mg} / \mathrm{kg}$ of body weight of Capparis spinosa extract protected rats against paracetamol liver injury lead to significantly increasing of reduced glutathione ( GSH ), catalase (CAT) and superoxide dismutase (SOD), and significantly lowering lipid peroxidation (LPO), manoldialdehyde (MDA), cholesterol and triglyceride levels .

The elevation in GSH, CAT and SOD and reduction LPO and MDA by using aqueous extract of Capparis spinosa comparing with posetive control and returning the biochemical parameters to normalization indicated that the aqueous extract of Capparis spinosa posses strong protective property against paracetamol- induced liver damage in rats.
\end{abstract}

Keywords : Capparis spinosa, paracetamol, antioxidant enzymes, lipid peroxidation, liver induced damage .

\section{تأثير المستخلص المائي لنبل الثفلح Capparis spinosa عل المتغيرك المضاكة لأكسةفي مطل الجرذل المعاملة بالبارلسيتامط لفبل}

\section{الملغص}

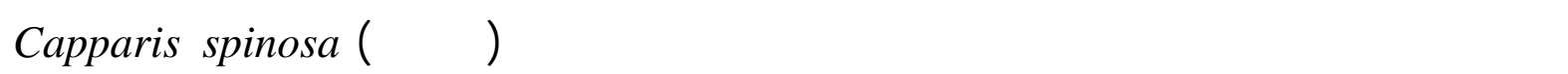

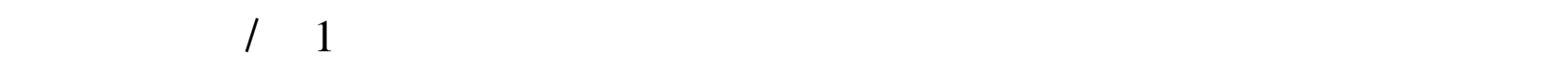

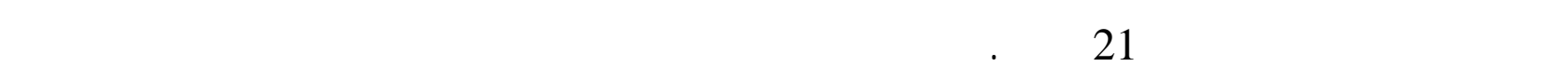

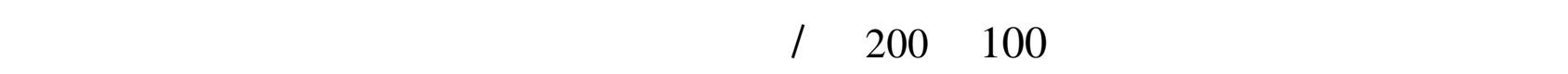

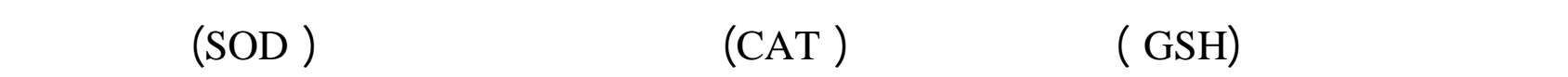

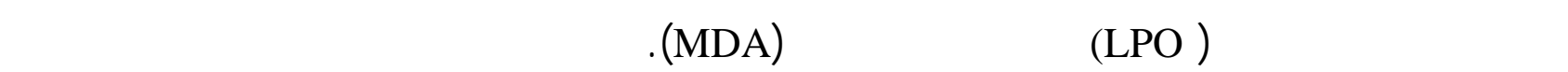




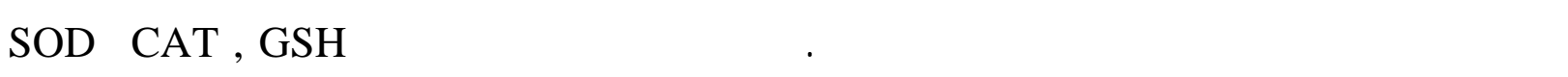

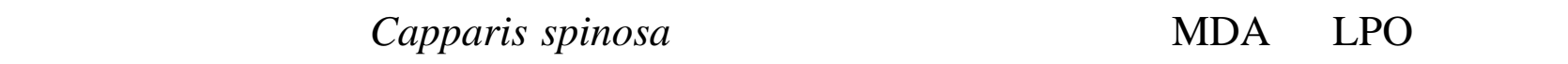

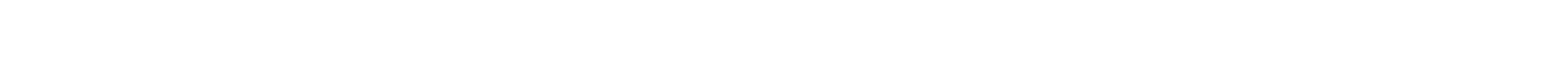
النبت صفة حموية ضد الضرر الكبدي المستحدث بالبارلسيتلمول في الجرذان. 